\title{
DYNAMICS OF KNOWLEDGE IN THE ECONOMIC SYSTEM FRAMEWORK: COGNITIVE APPROACH
}

\author{
DOI: 10.17261/Pressacademia.2019.1043 \\ JBEF- V.8-ISS.2-2019(5)-p.127-132
}

\author{
Aleria Irma Hatneny ${ }^{1}$, Ety Saraswati ${ }^{2}$, Ratna Tri Hardaningtyas ${ }^{3}$ \\ ${ }^{1}$ University of Islam Malang, Faculty of Economics and Business, Malang, Indonesia \\ aleriairmah@unisma.ac.id, ORCID: 0000-0002-3801-3777 \\ ${ }^{2}$ University of Islam Malang, Faculty of Economics and Business, Malang, Indonesia \\ etysaraswati@unisma.ac.id \\ ${ }^{3}$ University of Islam Malang, Faculty of Economics and Business, Malang, Indonesia \\ ratnatyas@unisma.ac.id
}

Date Received: April 4, 2019

Date Accepted: June 15, 2019

To cite this document

Hatneny, A. I., Saraswati, E., Hardaningtyas, R. T. (2019). Dynamics of knowledge in the economic system framework: Cognitive approach Journal of Business, Economics and Finance (JBEF), V.8(2), p.127-132, DOI: 10.17261/Pressacademia.2019.1043

Permemant link to this document: $\mathrm{http}: / /$ doi.org/10.17261/Pressacademia.2019.1043

Copyright: Published by PressAcademia and limited licenced re-use rights only.

\begin{abstract}
Methodology- Literature study presented in the form of conceptual framework of economic system from knowledge perspective. developed in regional economic studies.

Keywords: knowledge dynamics, economic system framework, regional economic studies JEL Codes: D83, P40, P48
\end{abstract}

Purpose- This paper aims to explore how the role of knowledge shapes concepts in an economic system framework.

Findings- By using literature study within cognitive approaches based on management theory, it can be explained how knowledge is processed, what environmental conditions are needed, and which actors are related. Furthermore, the relationship between concepts is discussed and

Conclusion- This paper confirms the importance of the role of knowledge as a key resource in economic system that can be adopted or

\section{INTRODUCTION}

In the regional economic context, the discussion of knowledge as a resource is less prominent than the discussion of human resources especially when it is associated with competitiveness and economic growth (Cadil, 2014, p. 85), so that the accumulation of knowledge and innovation is at a slower rate than in infrastructure and human resources (Zao, 2011, p. 46). Even if we want to explore the main sources of business and management issues that develop, knowledge becomes a very important essence. In the development history of evolution chain in management thinking, knowledge has always been the trigger for all business transformation. Starting from the industrial revolution in the 18th century, innovations have changed the production by using machines and no longer using human power (Stevenson, 2012). The invention of PC (Personal Computer) in the 1980s (O'Brien, 2003) to the internet era, can be said to be the result of the development of knowledge. Therefore, it is reasonable if we place knowledge as an important resource not only in the context of regional economics but also in other contexts.

The history of Japan's success emerging as an Asian economic giant in the 1980s is quite clear evidence of how knowledge resources can be managed into competitiveness on a regional scale. Zao $(2011$, p. 46) in his paper said, "Practice has proven that the environment and infrastructure are the core of local enterprises' innovation." Similar to Zao, Jeannerat (2016, p. 2) said that 
"... regional production systems may be competitive advantage in the global cumulative generation and exploitation of knowledge resources."

After being destroyed by a war and an atomic bomb by allies in 1945, Japan intensively developed a concept that we know as Total Quality Management (TQM), which originated from the thoughts of quality management teachers such as Edward Deming. Japan managed to combine the concept of quality management with Japanese philosophy which was elaborated from local culture such as working hard, never giving up and some others. Until the 1980s Japan with its steel production proved the efficiency and effectiveness of its industry by defeating American-made steel products (Gasperz, 2005).

As in corporate perspective, the nature of knowledge resources in regional contexts is not static but dynamic and always continues to evolve, adapt and renew itself at all times (Jeannerat, 2016, p. 4). Knowledge resources also have different characteristics because they do not experience any contraction unlike any other general resources (eg HR and capital) (Krumins, 2015, p. 117). With good regional knowledge management, it aims to create an innovative regional environment to create high competitiveness.

Most of the existing studies still focus on the corporate context. By looking at increasingly tight business competition it will be difficult for a company to achieve good competitiveness with its own strength. Synergy with the economic system surrounding is very important to strengthen its position. Thus, the need for study in the context of regional economic system is expected to answer these problems. The main concepts that will be discussed in this paper include; business environment, knowledge in the economic system and key actors in knowledge management.

\section{BUSINESS ENVIRONMENT}

The concept of a business environment must be well described, both from a vertical and horizontal perspective so that knowledge ecosystem can run well (Noennig, 2014, p. 1360-1362). Business environment itself also changes regularly or is so dynamic (Pachura, 2013). This is because (1) from the customer's perspective, market demands are always changing, (2) from its nature perspective, the knowledge itself is dynamic, which encourages the emergence of new innovations.

Although changes in the business environment are quite complex and can change with a scale that is difficult to predict, it can still be approached as a system (Noennig, 2014 and Jarvi, 2018). Noennig (2014) and Jarvi (2018) call the knowledge environment specifically as a system or 'ecosystem', which can be conceptually described in terms of relationships between entities in the ecosystem. In contrast, Jeannerat (2016) (figure 1) does not specifically describe the knowledge environment as a system, but only looking at the environment as limited to the concept of geography. Jeannerat focuses more on how knowledge proceeds through a system of production and consumption. However, Jeannerat can describe well how knowledge experiences its dynamics through renewals in a production and consumption system.

Figure 1: Conceptualizing an economic of knowledge valuation (Jeannerat, 2016)

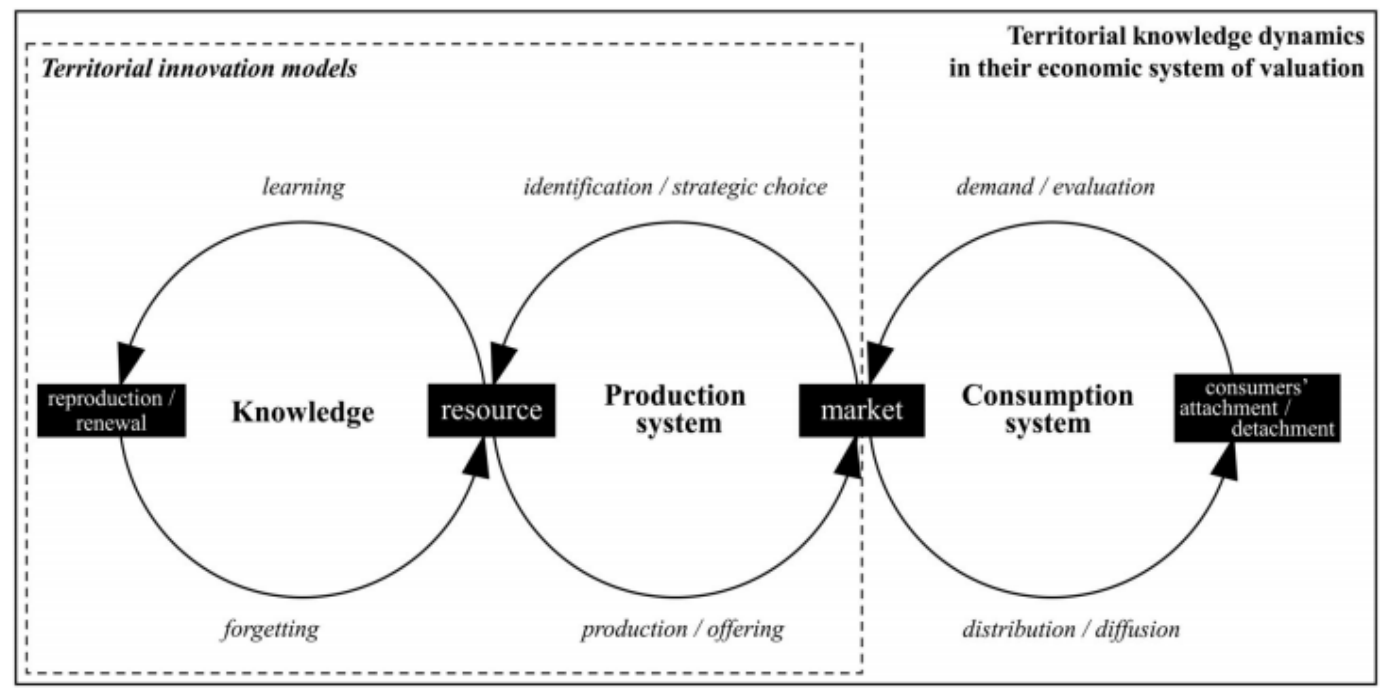


Business environment from regional perspective is also seen as an important aspect because it is a prerequisite for subsystems to work properly (Noennig, 2014) because environmental stability guarantees the effectiveness and efficiency of regional management (Zao, 2011). The relationship between the concept of environment and knowledge has often been observed and is a very important issue because knowledge ecosystem is considered as a driver of the birth of innovation. Disruptions to the environment because of the political situation and government regulations that are less supportive will disturb knowledge interactions (Gurvich, 2016).

From an internal-external point of view as a result of its regional scope, it is identical to the concept of the company. The difference is in a wider scale, where the level of uncertainty is high (Jeannerat, 2016) so that to realize it requires the organization and collectivity of the actors. It is different from the corporate context where internal-external boundaries are limited by production and consumption systems (Jeannerat, 2016).

The environment will influence strategy, both internal and externally. In principle, it is the same between company's economic system and regional economic system. Both can take the same approach using the I / O (Industrial Organization) and RBV (Resource-Based Model) models (Hitt, 2011) and Porter's 5 Forces Models (Williams, 2019; Hitt, 2011; O'Brien, 2003 and Laudon, 2012). But because of its wider scope, relations within the regional economic system are more complex. In complex relationships of dynamic environment, we must combine several approaches, not only one approach.

\section{KNOWLEDGE IN REGIONAL ECONOMIC SYSTEM}

Knowledge is key element in regional development and is an important content in regional management (Zao, 2011, p. 43-45). Continuity of regional development depends on the extent to which the effectiveness of the output of knowledge produced is able to follow changes in the environment. The nature of knowledge must also be understood as an environment that has high dynamics because it is always changing. Knowledge as a resource in an economic system can be understood as a cycle process where knowledge develops through the process. Using the TIM and TKD perspective, Jeannerat (2016) well illustrates how knowledge is absorbed into the production and consumption subsystems in a cycle within territorial area. Unfortunately, it does not discuss the environmental aspects.

In the regional context, the production system (Jeannerat, 2016, p. 3) can be compared with the interaction of 4 actors (Zao, 2010, p. 44) in an environment called the knowledge ecosystem (Noennig, 2014, p. 1360) so that it can form a conceptual framework. Knowledge ecosystems will become a production system that will result in the development of technology and innovation which will ultimately result in increasing regional competitive value (Zao, 2010; Pachura, 2013).

According to Jeannerat (2016) knowledge in an economic system will experience a process of co-evolution along with changes in the environment, so that to find the right strategy must be predictability (Zao, 2010). To simplify planning, Jeannerat (2016) categorizes Knowledge valuation according to its economic system into four; Knowledge Marketization, Knowledge Improvement, knowledge adaptation and knowledge co-development. Through different contexts, knowledge undergoes a renewal process due to market orientation, improvement and adaptation and development carried out collectively by all actors in the economic system.

Adopting the thought of Pachura (2013, p. 116), knowledge as a resource absorbed in production system (Jeannerat, 2016, p. 3) will be processed by actors in regional knowledge ecosystem where the process consists of "learning and transferring knowledge, sharing knowledge and creating innovation, interaction and trust arising from the cultural context and local environment. Similar to Pachura, Dirks and Ferrin (2001) in Keszey (2016, p. 3699) state the importance of trust. According to them, "trust is an essential element in positive human relationships and creates a collaborative environment by providing people with feelings of security and attachments."

The interaction between actors in regional knowledge system is considered as the most appropriate in the global era as it is today. Zao (2010) calls it "collective learning," while Jarvi (2018) calls it the "collectives knowledge ecosystem." Globalization causes the physical boundaries between systems to become increasingly blurred so that collective learning is not limited to internal (regional) information but can absorb information from global environment. Therefore, in the conceptual framework image (Figure 3), the regional boundary shows a dashed line illustrating that character. In fact, it does not rule out the possibility of collaboration between regions in the field of knowledge development (Zao, 2011; Jeannerat, 2016; Keszey, 2016; Pachura, 2013; Romanova et al., 2019; Vorontsov, 2015; Noennig, 2014). 


\section{KEY ACTORS}

Key actors who play many important roles in knowledge ecosystem are: First, the government (Zao, 2011; Pachura, 2013; Jarvi, 2018 and Jeannerat, 2016) through its institutions. They have a very crucial role because they are responsible for the environmental situations and conditions in which business people and other actors interact to develop knowledge. The government are also responsible for system infrastructure which ensures that the knowledge process can run well. A number of barriers to the flow of capital, resources and labor; incentives for new companies (Gurvich, 2016); transportation infrastructure and public services (Krumins, 2015 and Nakamura, 2013) are examples of the role of government in an economic system. For this reason, the government must always refer to global trends in the development of knowledge so that they are not left behind.

\section{Figure 2: Schematic representation of regional innovation (Zao, 2016)}

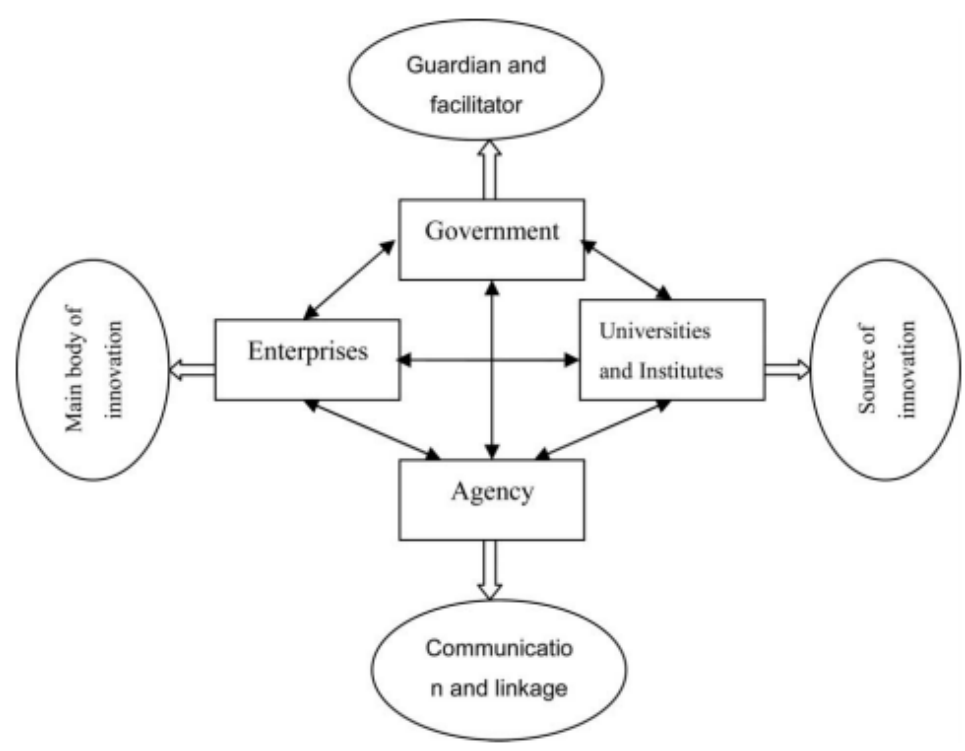

Second, academics include research institutions and universities (Zao, 2011; Pachura, 2013; Jarvi, 2018 and Jeannerat, 2016). As stated by Pachura (2013), "The scientific and research environment should also cooperate with companies." In this section Jarvi (2018, p. 1524) states that universities occupy key roles and central actors in the knowledge ecosystem.

Third, companies or business organizations (Zao, 2011; Pachura, 2013; Jarvi, 2018 and Jeannerat, 2016). Zao (2011) emphasizes the importance of companies as the spearhead in an economic system. Knowledge resources generated by research institutions and universities are absorbed and implemented by the company. Then the company embodies and delivers into the consumption system. Although its role is vital, but without a facilitator by other actors, it is impossible for a company to achieve optimal competitiveness.

The fourth is an intermediary agent (Zao, 2011), although it is not mentioned in other literature sources but this is quite interesting. In this regards, Zao (2011) appears to be so aware of the intermediation function represented by archives, museums, non-governmental institutions and others. Zao (2011) describes an intermediary agent as having an important role in strengthening the flow of communication and knowledge with the other three actors. Figure 2 shows four actors (Zao, 2011) that are different from the concept of 3 actors (Pachura, 2013; Jarvi, 2018 and Jeannerat, 2016). 


\section{CONCEPTUAL FRAMEWORK}

From the discussion above, relationships between concepts can be arranged in the form of a conceptual framework (figure 3 ) as follows:

Figure 3: Regional Knowledge Value Chain (own elaboration from several sources)

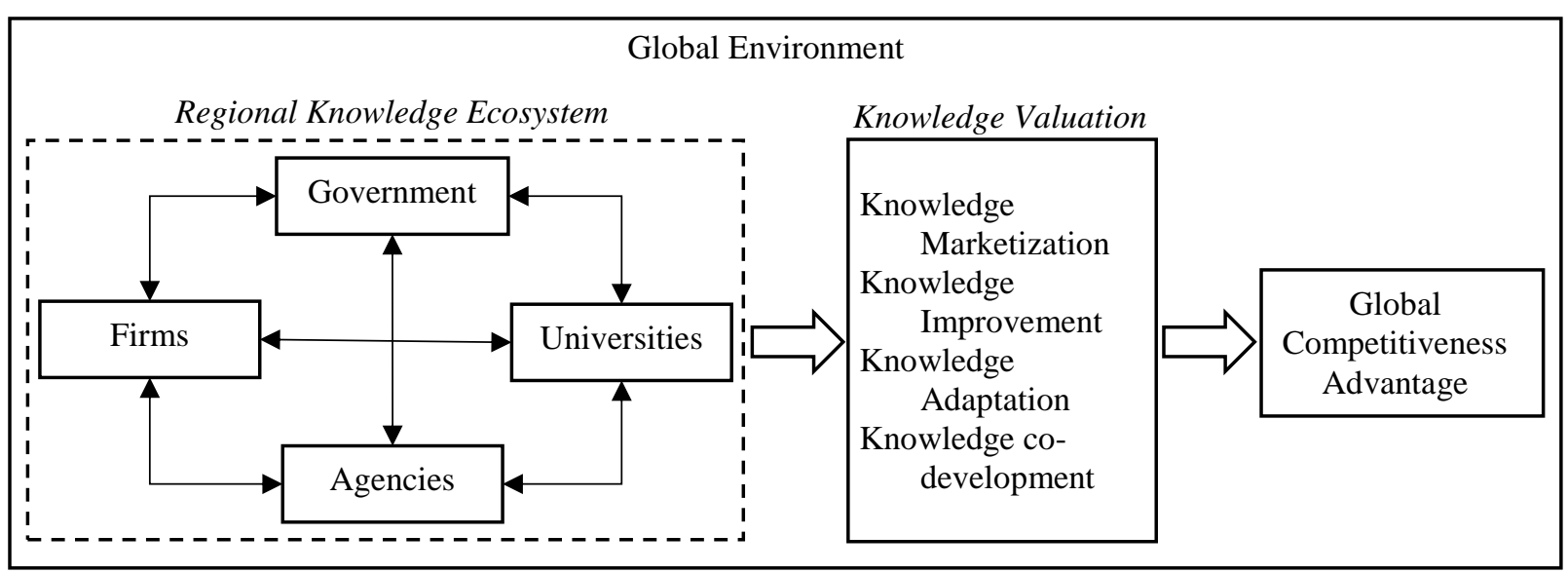

\section{CONCLUSION}

In the value chain context, the value of knowledge is not only important, but knowledge also becomes the core, or ranks first, in the value chain. Then good understanding of how knowledge is absorbed, how it is processed and developed, is also important because it will determine the quality of output that will be produced in a value chain.

The concept of "ecosystem" in the field of natural science turned out to be used also in the field of economics. Borrowing the term "ecosystem" can help explain how knowledge is absorbed, processed, and developed through the interaction of actors in regional economic system. Regional knowledge ecosystems are the key to whether creation, improvement, development of innovation can work well. In this case the government with its regulations and policies will determine the conductivity of the interaction of other actors in the knowledge value chain process.

In the regional knowledge context, the creation and development of competitive values depend on knowledge ecosystem in the region. Good collaboration between 4 actors (government, universities/research institution, agencies and firms) in the ecosystem is crucial for regional competitiveness.

This paper has not discussed the factors that can hinder the process of regional value chain knowledge. It is suggest that further analysis can deepen and broaden some more understandings of knowledge in the context of regional economics. Because the environment is always changing, new concepts and new propositions will continue to emerge in place of the old ones. 


\section{REFERENCES}

Cadil, J., Petkovova, L. and Blatna, D. (2014). Human Capital, Economic Structure and Growth. Procedia Economics and Finance. 12. 85-92

Gasperz, V. (2005). Total Quality Management. Jakarta: PT. Gramedia Pustaka Umum

Gurvich, Evsey. (2016). Institutional constraints and economic development. Russian Journal of Economics. 2. 349-374

Hitt, M.A., Ireland, R.D. and Hoskisson, R. E. (2011). Strategic Management: Competitiveness and Globalization Concepts. 9th Edition. SouthWestern Cengage Learning

Jarvi, K., Almpanopoulou, A. and Ritala, P. (2018). Organization of Knowledge Ecosystems: Prefigurative and Partial Forms. Research Policy. 47. 1523-1537

Jeannerat, H. and Kebir, L. (2016). Knowledge, Resources and Markets: What Economic System of Valuation? Regional Studies. 50. 274-288

Krumins, G., Krumina, I. and Rozentale S. (2015). Preconditions for Regional Economic Growth at the District Level in Vidzeme, Latvia. Procedia Social and Behavioral Sciences. 213. 117-122

Laudon, Kenneth C. and Laudon, Jane P. (2012). Management Information System: Managing the Digital Firm. 12th Edition. Pearson Education Inc.

Noennig, J.R., Scheler, A.M., Piskorek, K., and Barski, J. (2014) Towards knowledge ecosystems: Modelling Knowledge Dynamics in Environmental Systems. Procedia Computer Science. 35. 1360-1369

O’Brien, J.A. and Marakas, G.M. (2003). Management Information System, 10th Edition, New York: McGraw-Hill Irwin

Pachura, P. (2013). “Cognitive Economic Geography”- Evolution of Regional Strategies. Procedia Economics and Finance. 6. 115-119

Romanova, A., Abdurakhmanov, A., Ilyin V., Vygnanova, M. and Skrebutene, E. (2019). Formation of a Regional industrial cluster on the basis of coordination of business entities' interests. Procedia Computer Science. 149. 525-528

Stevenson, William J. (2012). Operations Management 11 th ed. New York. McGraw-Hill

Vorontsov, D., Shikhalev, A. and Semushina, K. (2015).Using of cultural heritage in the socio-economic development strategy of the EU regions. Procedia - Social and Behavioral Sciences. 188. 163-169

Williams, Kevan. (2009). Strategic Management. New York. DK Publishing

Zhao, J. and de Pablos, P.O. (2011). Regional knowledge management: the perspective of management theory. Behaviour \& Information Technology. 30. 39-49 